\title{
PENGARUH JUMLAH RUAS DAN ZAT PENGATUR TUMBUH TERHADAP PERTUMBUHAN STEK PRANAJIWA (Euchresta horsfieldii (Lesch.) Benth
}

\author{
The effect number of nodes and growth hormone of pranajiwa \\ (Euchresta horsfieldii (Lesch.)Benth.) \\ I M. Ardaka, I G. Tirta dan/and Dw Pt. Darma \\ UPT.Balai Konservasi Tumbuhan Kebun Raya "Eka Karya” Bali-LIPI \\ Candikuning, Tabanan, Bali \\ ardhaimade@yahoo.com
}

Naskah masuk : 23 April 2010; Naskah diterima : 28 Maret 2011

\begin{abstract}
The study on the effect of nodes and concentration on growth of pranajiwa (Euchresta horsfieldii (Lesch.) Benth have been done at "Eka Karya" Bali Botanic Garden-LIPI, Tabanan, from July to Desember 2009. The treatmens were growth hormone such as atonik, IAA,rootone-f and water in combination with number of nodes :1, 2 and 3. The experimental are completely randomized block design with three replications. The parameter observed were, the amount of the first shoot growth, the amount of growth nodes, leaves, and roots, shoot height, and roots length. Observation result, hormone atonik with number of nodes 3 at stimulating the optimum growth for on propagation with vegetative pranajiwa withof life persentage $90 \%$, the amount of growth leaves 2,90 sheets, shoot height $0,77 \mathrm{~cm}$, roots length $3,37 \mathrm{~cm}$ and number of roots $9,00 \mathrm{~cm}$.
\end{abstract}

Keywords: Number of nodes, pranajiwa (Euchresta horsfieldii (Lesch.)Benth, nodes, growth hormone

\begin{abstract}
ABSTRAK
Studi pengaruh jumlah ruas dan zat pengatur tumbuh terhadap pertumbuhan stek pranajiwa (Euchresta horsfieldii (Lesch.) Benth dilaksanakan di Kebun Raya "Eka Karya" Bali - LIPI, pada bulan Juli sampai Desember 2009. Perlakuannya adalah zat pengatur tumbuh atonik $\left(A_{1}\right)$, IAA $\left(A_{2}\right)$, rootone- $f\left(A_{3}\right)$ dan air matang $\left(\mathrm{A}_{4}\right)$ yang dikombinasikan dengan jumlah ruas pada stek pucuk yaitu stek satu ruas $\left(\mathrm{B}_{1}\right)$, stek dua ruas $\left(\mathrm{B}_{2}\right)$ dan stek tiga ruas $\left(\mathrm{B}_{3}\right)$. Penelitian ini menggunakan rancangan acak lengkap faktoril (RALF) dengan tiga ulangan. Parameter yang diamati adalah jumlah hari tumbuh tunas (hst), jumlah stek yang tumbuh, jumlah daun, tinggi tunas, jumlah akar dan panjang akar. Dari hasil penelitian dapat disimpulkan bahwa zat pengatur tumbuh atonik dengan stek pucuk yang beruas tiga $\left(\mathrm{A}_{1} \mathrm{~B}_{3}\right)$ paling baik digunakan dalam memperbanyak pranajiwa secara vegetative dengan persentase hidup $90 \%$, pertumbuhan jumlah daun 2,90 helai, tinggi $0,77 \mathrm{~cm}$, panjang akar 3,37 $\mathrm{cm}$ dan jumlah akar $9,00 \mathrm{~cm}$.
\end{abstract}

Kata kunci : Jumlah ruas, pranajiwa (Euchresta horsfieldii (Lesch.) Benth, stek, zat pengatur tumbuh

\section{PENDAHULUAN}

Banyaknya masyarakat yang tinggal di pedesaan terutama daerah yang sulit dijangkau (terisolir) menyebabkan pemerataan hasil-hasil pembangunan seperti pendidikan dan kesehatan sulit untuk dilaksanakan. Namun pada daerahdaerah terisolir pemanfaatan lingkungan terutama tumbuhan untuk pemenuhan kebutuhan kesehatan seperti untuk obat-obatan tradisional sangat tinggi.

Pranajiwa (Euchresta horsfieldii) (Gambar 1) termasuk dalam suku Fabaceae, merupakan salah satu tumbuhan hutan yang berpotensi sebagai sumber obat tradisional Indonesia. Tumbuhan ini hidup pada hutan yang 
banyak naungannya dengan serasah tebal sebagai humus hutan. Berdasarkan mitos buah dari tanaman ini merupakan makanan harimau penjaga di sekitar pura.

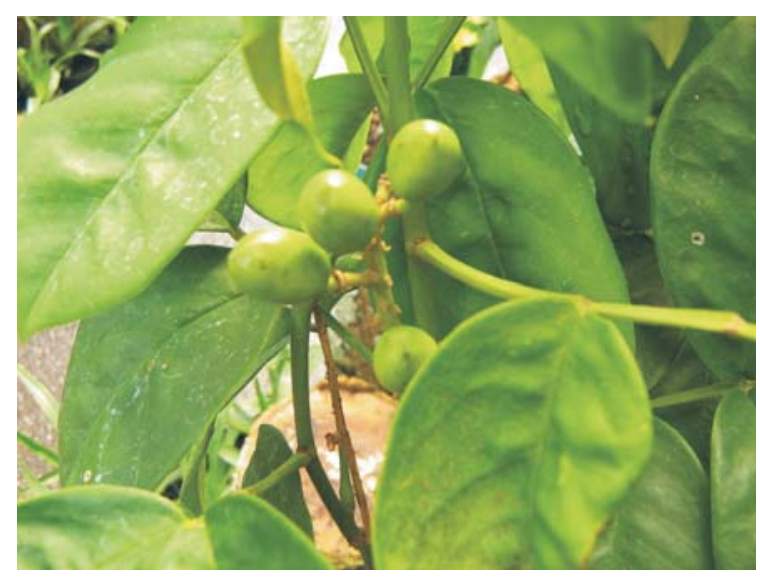

Gambar(figure) 1. Tumbuhan Pranajiwa (Pranajiwa plant)

Secara tradisional biji pranajiwa khasiatnya hanya dikenal terbatas di kalangan keluarga maupun masyarakat tertentu, yaitu sebagai penyegar tubuh dan sebagai obat perangsang. Dalam perkembangan selanjutnya, karena populer khasiatnya, saat ini telah diproduksi oleh industri jamu menjadi suatu komoditas yang bernilai ekonomi dalam berbagai macam produk jadi. Akar dan batang-nya mengandung flavonoid isoflavones, pterocarpans, caumaronochromones dan flavonones. Jenis flavonoid yang terdapat pada daun adalah apigenin. Bijinya mengandung alkaloid berupa cytosine $(1,5 \%)$, matrine dan matrine-N-oxide. Yang dapat digunakan sebagai obat sakit TBC, perangsang syahwat, penyakit dada dan muntah darah (Heyne, 1987).

Sebagai konsekuensi dari peningkatan produksi obat tradisional maka kebutuhan akan bahan baku terus meningkat. Selama ini telah diketahui bahwa sebagian besar tumbuhan obat penghasil bahan baku masih diperoleh dari alam yang merupakan tumbuhan liar dan hanya sebagian kecil saja yang diperoleh dari hasil budidaya. Fase generatif dari tanaman ini yaitu membentuk bunga pada bulan September November dan buah sampai matang pada bulan Desember - Juli. Biji yang dapat dipakai bahan perbanyakan sangat sulit dijumpai sehingga perbanyakan dilakukan dengan cara vegetatif; berdasarkan penelitian yang telah dilaksanakan Hartutingsih, dkk. (2003) purnajiwa dapat diperbanyak lewat stek dengan menggunakan atonik, stek pucuk lebih cepat membentuk tunas, dan akar, namun jumlah stek hidup yang mempunyai pertumbuhan baik masih relatif rendah $(33,33 \%)$ dan berdasarkan penelitian Ardaka $d k k$. (2007), media yang paling baik digunakan dalam memperbanyak purnajiwa dengan cara vegetatif (stek pucuk) adalah cacahan akar kadaka yang menghasilkan persentase hidup stek paling tinggi di antara media yang lain. Untuk itu perlu dilakukan penelitian perbanyakan lanjutan dengan perlakuan jumlah ruas dan zat pengatur tumbuh. Permasalahan yang dihadapi pada penelitian sebelumnya adalah masih kecilnya persentase tumbuh. Tujuan penelitian ini adalah untuk mengetahui jumlah ruas stek dan zat pengatur tumbuh yang tepat dan sesuai untuk memperbanyak stek pucuk pranajiwa. Diharapkan hasil penelitian ini bermanfaat untuk memecahkan cara perbanyakan tumbuhan yang berkhasiat obat dan langka.

\section{BAHAN DAN METODE}

Penelitian ini dilakukan pada bulan Juli sampai Desember 2009 di Pembibitan Kebun Raya "Eka Karya" Bali. Bahan yang digunakan adalah stek pucuk pranajiwa yang diperoleh dari Bukit Sangiang cagar Alam Batukau Kabupaten Tabanan. Media yang dipergunakan adalah akar kadaka (Asplenium nidus L.) yang dicacah sampai halus dan disterilisasi dengan air panas kemudian ditutup dengan plastik. Pot plastik yang sudah diisi media diletakkan pada bak yang terbuat dari papan. Stek pucuk yang terdiri dari satu ruas, dua ruas dan tiga ruas diberi perlakuan zat pengatur tumbuh atonik $\left(1,5 \mathrm{ml} \operatorname{ltr}^{-1}\right)$, IAA, Rootone-f yang dioleskan pada pangkal stek secukupnya dan sebagai kontrol stek direndam pada air matang selama 10 menit. Stek ditanam pada media yang sudah disteril kemudian disungkup plastik transparan untuk mengurangi penguapan. Penyiraman melalui peresapan yang dilakukan dengan mengisi air pada bak agar stek tidak goyah.

Rancangan yang digunakan pada penelitian ini adalah Rancangan acak lengkap faktorial (RALF) dengan 4 perlakuan zat pengatur tumbuh yaitu : atonik $\left(\mathrm{A}_{1}\right)$, IAA $\left(\mathrm{A}_{2}\right)$, rootone-f $\left(\mathrm{A}_{3}\right)$ dan air matang $\left(\mathrm{A}_{4}\right)$ yang dikombinasikan dengan jumlah ruas pada stek pucuk yaitu stek satu ruas $\left(B_{1}\right)$, stek dua ruas $\left(B_{2}\right)$ dan stek tiga ruas $\left(\mathrm{B}_{3}\right)$, sehingga akan ada 12 kombinasi perlakuan (Gambar 2). Masingmasing perlakuan diulang 3 kali. Di setiap 
perlakuan dalam satu ulangan terdapat 10 stek sehingga dalam percobaan ini terdapat 360 stek. Analisa data menggunakan beda nyata terkecil.

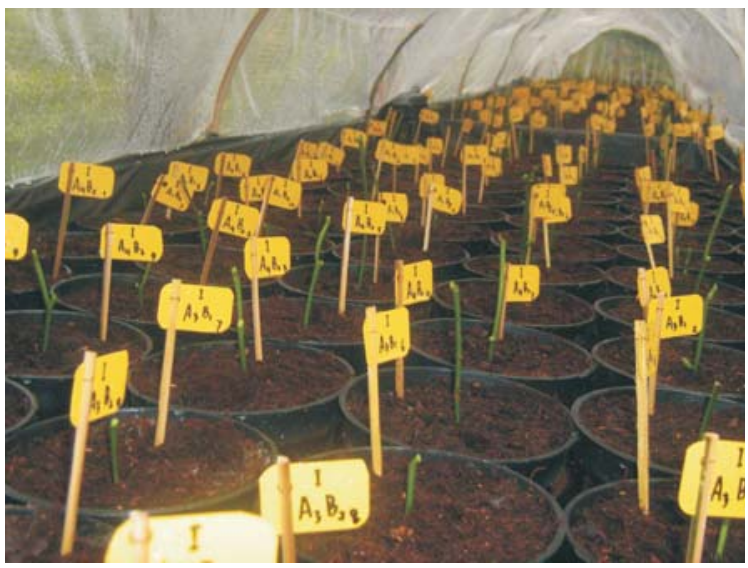

Gambar (figure)2. Perlakuan penelitian (research treatments)

Parameter yang diamati adalah jumlah hari tumbuh tunas (hst), jumlah stek yang tumbuh, jumlah daun, tinggi tunas. Untuk mengatahui sistem perakaran yang terbentuk dilakukan pembongkaran untuk mengetahui jumlah dan panjang akar. Pengamatan dilaksanakan mulai dari seragamnya perlakuan tumbuh tunas

\section{HASIL DAN PEMBAHASAN}

Pengamatan tumbuh tunas dilaksanakan pada umur 15 hari setelah tanam sedangkan tinggi tunas, jumlah anak daun pada umur 100 hari setelah tanam serta jumlah akar dan panjang akar pada umur 130 hari setelah tanam. Waktu hari stek tumbuh tidak berbeda nyata pada semua perlakuan dengan rata-rata tumbuh 23.8 hari. Stek Pranajiwa tidak menumbuhkan tunas yang banyak seperti yang tumbuh di alam antara 1 - 3 tunas. Setelah tunas menjadi batang dan pucuknya menghasilkan bunga serta buah, pucuk ini mati. Tunas baru akan tumbuh di bawah tangkai buah yang sudah mati, begitu seterusnya.

Tabel (Table) 1. Pengaruh zat pengatur tumbuh (A) dan jumlah ruas (B) terhadap \% (persentase) hidup stek pranajiwa (Effect growth hormone and number of nodes to \% of cutting life)

\begin{tabular}{|c|c|c|c|}
\hline \multirow{2}{*}{$\begin{array}{c}\text { Zat Pengatur Tumbuh } \\
\text { (growth hormone) (A) }\end{array}$} & \multicolumn{3}{|c|}{ Jumlah Ruas (Number of nodes) (B) } \\
\cline { 2 - 4 } & B1 & B2 & B3 \\
\hline A1 & $30 \mathrm{~b}$ & $83,33 \mathrm{c}$ \\
A2 & $3,33 \mathrm{a}$ & $3,33 \mathrm{a}$ & $20 \mathrm{ab}$ \\
A3 & $36,67 \mathrm{~b}$ & $76,67 \mathrm{c}$ & $90 \mathrm{~d}$ \\
A4 & $50 \mathrm{bc}$ & $80 \mathrm{c}$ & $93,33 \mathrm{~d}$ \\
\hline
\end{tabular}

Catatan (Note): Nilai-nilai dalam kolom yang diikuti oleh huruf yang berbeda menunjukkan perbedaan yang nyata pada taraf $\mathrm{p}<$ 0,05 menurut uji Beda Nyata Ter-kecil (Values in colums followed by different indi-cate significant differences at the $p<0.05$ level according to the Least Significant Difference Test)

Stek pada perlakuan $\mathrm{A}_{4} \mathrm{~B}_{3}$ (Kontrol/ perendaman dengan air matang dan stek tiga ruas) persentase stek tumbuh paling tinggi yaitu $93,33 \%$, berbeda sangat nyata dengan perlakuan $\mathrm{A}_{2} \mathrm{~B}_{1}, \mathrm{~A}_{2} \mathrm{~B}_{2}$ (zat pengatur tumbuh IAA dengan 1 ruas dan 2 ruas) yang persentase stek hidup paling sedikit yaitu masing-masing 3,33 \% (Tabel 1). Persentase stek pucuk tumbuh paling banyak adalah pada stek beruas tiga yang tidak diberi perlakuan zat pengatur tumbuh, dapat diduga bahwa stek pucuk pranajiwa sudah mengandung auksin alami yang cukup dalam membentuk akar dan cadangan makanan pada stek beruas tiga merupakan batas minimal dalam membentuk akar. Cadangan makanan yang berupa karbohidrat dan nitrogen pada ruas dapat meningkatkan jumlah tumbuh stek disebabkan oleh hormon tumbuh yang berfungsi sebagai perangsang dalam pertumbuhan dan perkembangan tanaman tersebut. Suatu tanaman akan tumbuh dengan subur apabila segala elemen yang dibutuhkan selalu cukup tersedia. Tingginya 
stek tumbuh akibat pemberian zat pengatur tumbuh dan konsentrasi yang sesuai akan mengakibatkan peningkatan kandungan auksin di daerah pucuk bagian atas tanaman. Auksin adalah salah satu hormon pertumbuhan yang mempunyai pengaruh paling besar pada pertumbuhan akar (Hartman and Kester, 1977).

Jumlah anak daun yang tumbuh berpengaruh sangat nyata $(P<0,01)$ pada stek yang diberi perlakuan $\mathrm{A}_{1} \mathrm{~B}_{3}$ (zat pengatur tumbuh atonik dengan stek tiga ruas) dengan pertumbuhan daun pada hari ke 100 dan 130 hari setelah tanam rata-rata 2,53 helai dan 2,90 helai sedangkan stek yang diberi perlakuan zat pengatur tumbuh IAA dengan 1 ruas dan 2 ruas $\left(\mathrm{A}_{2} \mathrm{~B}_{1}, \mathrm{~A}_{2} \mathrm{~B}_{2}\right.$ ) pada hari ke-100 dan 130 hari setelah tanam belum menumbuhkan anak daun (Tabel 2.). Jumlah anak daun sangat berkaitan dengan jumlah stek yang tumbuh tunas. Cadangan makanan yang berupa karbohidrat dan nitrogen pada stek dapat meningkatkan jumlah daun pada tanaman. Suatu tanaman akan tumbuh dengan suburnya apabila segala elemen yang dibutuhkan selalu cukup tersedia seperti hormon tumbuh yang berfungsi sebagai perangsang dalam pertumbuhan dan perkembangan tanaman (Sutatar dan Sanjaya, 1996). Efektivitas zat pengatur tumbuh menurun pada intensitas cahaya rendah, oleh karena itu pemakaian zat pengatur tumbuh haruslah disertai dengan pengaturan lingkungan pertanaman yang optimal bagi pertumbuhan dan perkembangan tanaman. Zat Pengatur tumbuh pada konsentrasi yang tepat dan cara pemberian yang benar terbukti memacu pembelahan dan pemanjangan sel-sel daun (Surachmat, K. 1984).
Interaksi antara zat pengatur tumbuh dan jumlah ruas pada stek pucuk berpengaruh sangat nyata $(\mathrm{P}<0,01)$ terhadap variabel tinggi tunas pada hari ke-130 hst (Tabel 3). Perlakuan $\mathrm{A}_{1}, \mathrm{~A}_{3}$ dan $\mathrm{A}_{4}$ yang dikombinasikan dengan stek beruas $\mathrm{B}_{1}, \mathrm{~B}_{2}$ dan $\mathrm{B}_{3}$ pertumbuhan tinggi tunas berpengaruh sangat nyata dan berpengaruh nyata dengan perlakuan $A_{2}$ yang dikombinasikan dengan stek beruas $\mathrm{B}_{1}, \mathrm{~B}_{2}$ dan $\mathrm{B}_{3}$ karena pada perlakuan ini tidak ada pertumbuhan tinggi tunas $\left(\begin{array}{ll}0 & \mathrm{~cm}\end{array}\right)$. Peningkatan kandungan auksin disebabkan oleh dua kemungkinan yaitu menurunnya ketidak aktifan auksin atau meningkatnya sintesis auksin. Di dalam sel tanaman IAA teroksidasi menjadi tidak aktif oleh peroksidase dan IAA oksidase (Krishnamorthy, 1981 dalam Sutatar T dan L. Sanjaya, 1996).

Stek yang ditanam dengan perlakuan $\mathrm{A}_{1}$, $A_{3}$ dan $A_{4}$ yang dikombinasikan dengan stek beruas $\mathrm{B}_{1}, \mathrm{~B}_{2}$ dan $\mathrm{B}_{3}$, pertumbuhan tunas optimal dan sehat. Hal ini diduga karena faktor cadangan makanan dan berbagai hormon pertumbuhan yang terdapat pada stek relatif cukup tersedia untuk memenuhi kebutuhan awal pertumbuhan, terutama perlakuan $\mathrm{A}_{1} \mathrm{~B}_{3}$, $\mathrm{A}_{3} \mathrm{~B}_{3}$ dan $\mathrm{A}_{4} \mathrm{~B}_{3}$ yang pertumbuhan tinggi tunas sangat optimal yaitu rata-rata $0,77 \mathrm{~cm}, 0,64 \mathrm{~cm}$ dan $0,55 \mathrm{~cm}$ (Tabel 4.) Peningkatan tinggi tanaman akibat pemberian zat pengatur tumbuh pada konsentrasi yang sesuai disebabkan oleh peningkatan kandungan auksin di daerah pucuk bagian atas tanaman. Auksin adalah salah satu hormon pertumbuhan yang mempunyai pengaruh paling besar pada pertumbuhan akar (Hartman and Kester, 1975).

Tabel(Table) 2. Pengaruh zat pengatur tumbuh (A) dan jumlah ruas (B) terhadap jumlah daun (Effect growth hormone and number of nodes to the amount of growth leaves)

\begin{tabular}{|c|c|c|c|c|c|c|}
\hline \multirow[b]{3}{*}{$\begin{array}{l}\text { Zat Pengatur Tumbuh } \\
\text { (growth hormone) } \\
\text { (A) }\end{array}$} & \multicolumn{6}{|c|}{ Jumlah Ruas (number of nodes) (B) } \\
\hline & \multicolumn{2}{|c|}{ B1 } & \multicolumn{2}{|c|}{$\mathrm{B} 2$} & \multicolumn{2}{|c|}{ B3 } \\
\hline & $\begin{array}{l}\text { Jumlah daun } \\
\text { (Number } \\
\text { of leaves) } \\
100 \text { hst } \\
\text { (100 to day) }\end{array}$ & \begin{tabular}{|} 
Jumlah daun \\
(Number \\
of leaves) \\
$130 \mathrm{hst}$ \\
(100 to day)
\end{tabular} & $\begin{array}{c}\text { Jumlah daun } \\
\text { (Number } \\
\text { of leaves) } \\
100 \mathrm{hst} \\
\text { (100 to day) }\end{array}$ & \begin{tabular}{|} 
Jumlah daun \\
(Number \\
of leaves) \\
$130 \mathrm{hst}$ \\
(100 to day)
\end{tabular} & $\begin{array}{c}\text { Jumlah daun } \\
\text { (Number } \\
\text { of leaves) } \\
100 \mathrm{hst} \\
\text { (100 to day) }\end{array}$ & \begin{tabular}{|} 
Jumlah daun \\
(Number \\
of leaves) \\
$130 \mathrm{hst}$ \\
(100 to day)
\end{tabular} \\
\hline A1 & $0,13 \mathrm{a}$ & $0,17 \mathrm{a}$ & $1,03 \mathrm{ab}$ & $1,33 \mathrm{ab}$ & $2,53 \mathrm{~b}$ & $2,90 \mathrm{~b}$ \\
\hline $\mathrm{A} 2$ & $0 \mathrm{a}$ & $0 \mathrm{a}$ & $0 \mathrm{a}$ & $0 \mathrm{a}$ & $0,10 \mathrm{a}$ & $0,10 \mathrm{a}$ \\
\hline A3 & $0,07 \mathrm{a}$ & $0,07 \mathrm{a}$ & $1,37 \mathrm{ab}$ & $1,43 \mathrm{ab}$ & $1,67 \mathrm{ab}$ & $2,27 \mathrm{~b}$ \\
\hline A4 & $0,07 \mathrm{a}$ & $0,10 \mathrm{a}$ & $0,80 \mathrm{a}$ & $0,87 \mathrm{a}$ & $2,33 \mathrm{~b}$ & $2,50 \mathrm{~b}$ \\
\hline
\end{tabular}

Catatan (Note) : Nilai-nilai dalam kolom yang diikuti oleh huruf yang berbeda menunjukkan perbedaan yang nyata pada taraf $\mathrm{p}<0,05$ menurut uji Beda Nyata Terkecil (Values in colums followed by different indi-cate significant differences at the $p<0.05$ level according to the Least Significant Difference Test) 
Tabel(Table) 3. Pengaruh perlakuan jumlah ruas dan zat pengatur tumbuh terhadap pertumbuhan stek pucuk pranajiwa (Effect number of nodes and growth hormone to the growth variable of cutting pranajiwa)

\begin{tabular}{|c|c|c|c|c|}
\hline \multirow{2}{*}{ No } & \multirow{2}{*}{ Variabel(Variable) } & \multicolumn{3}{|c|}{ Perlakuan (Treatments) } \\
\hline & & A & $\mathrm{B}$ & $\mathrm{A} \mathrm{X} \mathrm{B}$ \\
\hline 1 & $\begin{array}{l}\text { Saat tumbuh tunas(Number of days of the first shoot } \\
\text { growth) }\end{array}$ & tn & tn & tn \\
\hline 2 & $\begin{array}{l}\text { Jumlah stek hidup (Number of cutting life) } \\
\text { hari ke-130 setelah tanam(130 to day) }\end{array}$ & $* *$ & $* *$ & $* *$ \\
\hline 3 & $\begin{array}{l}\text { Jumlah anak daun (helai) (Number of leaves) } \\
\text { hari ke-100 setelah tanam (100 to day) } \\
\text { hari ke-130 setelah tanam (130 to day) }\end{array}$ & ** & ** & ** \\
\hline 4 & $\begin{array}{l}\text { Tinggi tunas (Height of shoots) (cm) } \\
\text { hari ke-130 setelah tanam (130 to day) }\end{array}$ & $* *$ & $* *$ & $* *$ \\
\hline 5 & $\begin{array}{l}\text { Jumlah Akar (Number of roots) } \\
\text { hari ke-130 setelah tanam (130 to day) }\end{array}$ & $* *$ & $* *$ & $* *$ \\
\hline 6 & $\begin{array}{l}\text { Panjang Akar (Roots length) }(\mathrm{cm}) \\
\text { hari ke-130 setelah tanam }(130 \text { to day) }\end{array}$ & $* *$ & $* *$ & $* *$ \\
\hline
\end{tabular}

Keterangan: * = berpengaruh nyata $(\mathrm{P}<0,05), * *=$ berpengaruh sangat nyata $(\mathrm{P}<0,01)$, th $=$ berpengaruh tidak nyata $(\mathrm{P}>0,05$, $\mathrm{A}=$ Zat Pengatur tumbuh, $\mathrm{B}=$ Jumlah Ruas pada stek (Values in colums followed by different indi-cate significant differences at the $p<0.05$ level according to the Least Significant Difference Test)

Tabel (Table) 4. Pengaruh zat pengatur tumbuh (A) dan jumlah ruas (B) terhadap tinggi tunas, panjang dan jumlah Akar (Effect growth hormone and number of nodes to the amount of growth of nodes length and roots height and number of roots).

\begin{tabular}{|c|c|c|c|c|c|c|c|c|c|}
\hline \multirow{3}{*}{$\begin{array}{c}\text { Zat } \\
\text { Pengatu } \\
\mathrm{r} \\
\text { Tumbu } \\
\mathrm{h} \\
\text { (growth } \\
\text { hormon } \\
\text { e) } \\
\text { (A) }\end{array}$} & \multicolumn{9}{|c|}{ Jumlah Ruas (number of nodes) (B) } \\
\hline & \multicolumn{3}{|c|}{ B1 } & \multicolumn{3}{|c|}{$\mathrm{B} 2$} & \multicolumn{3}{|c|}{ B3 } \\
\hline & $\begin{array}{l}\text { Pertumbuh } \\
\text { an tinggi } \\
\text { tunas (To } \\
\text { growth of } \\
\text { nodes } \\
\text { lenght }\end{array}$ & $\begin{array}{l}\text { Panjang } \\
\text { akar } \\
\text { (Roots } \\
\text { height }\end{array}$ & $\begin{array}{l}\text { Jumlah } \\
\text { akar } \\
\text { (Numb } \\
\text { er of } \\
\text { roots) }\end{array}$ & $\begin{array}{l}\text { Pertumbuh } \\
\text { an tinggi } \\
\text { tunas (To } \\
\text { growth of } \\
\text { nodes } \\
\text { lenght }\end{array}$ & $\begin{array}{l}\text { Panjang } \\
\text { akar } \\
\text { (Roots } \\
\text { height }\end{array}$ & $\begin{array}{l}\text { Jumlah } \\
\text { akar } \\
\text { (Numb } \\
\text { er of } \\
\text { roots) }\end{array}$ & $\begin{array}{l}\text { Pertumb } \\
\text { uhan } \\
\text { tinggi } \\
\text { tunas } \\
\text { (To } \\
\text { growth } \\
\text { of nodes } \\
\text { lenght }\end{array}$ & $\begin{array}{l}\text { Panjang } \\
\text { akar } \\
\text { (Roots } \\
\text { height }\end{array}$ & $\begin{array}{l}\text { Jumlah } \\
\text { akar } \\
\text { (Numb } \\
\text { er of } \\
\text { roots) }\end{array}$ \\
\hline A1 & $0,06 \mathrm{a}$ & $0,03 \mathrm{a}$ & $0,67 a$ & $0,34 \mathrm{ab}$ & $0,50 \mathrm{a}$ & $2,00 \mathrm{~b}$ & $0,77 \mathrm{~b}$ & $3,37 \mathrm{c}$ & $9,00 \mathrm{~d}$ \\
\hline A2 & $0 \mathrm{a}$ & 0a & $0 \mathrm{a}$ & $0 \mathrm{a}$ & $0 \mathrm{a}$ & $0 \mathrm{a}$ & $0 \mathrm{a}$ & 0a & 0a \\
\hline $\mathrm{A} 3$ & $0,02 \mathrm{a}$ & $0,83 a$ & $0,67 \mathrm{a}$ & $0,53 \mathrm{~b}$ & $1,87 \mathrm{ab}$ & $5,67 \mathrm{c}$ & $0,64 \mathrm{~b}$ & $2,47 \mathrm{~b}$ & $8,67 \mathrm{~d}$ \\
\hline A4 & $0,09 \mathrm{a}$ & $0 \mathrm{a}$ & $0 \mathrm{a}$ & $0,33 \mathrm{ab}$ & $1,90 \mathrm{ab}$ & $2,67 \mathrm{~b}$ & $0,55 \mathrm{~b}$ & $2,30 \mathrm{~b}$ & $5,33 \mathrm{c}$ \\
\hline
\end{tabular}

Catatan (Note): Nilai-nilai dalam kolom yang diikuti oleh huruf yang berbeda menunjukkan perbedaan yang nyata pada taraf $\mathrm{p}<0,05$ menurut uji Beda Nyata Terkecil (Values in colums followed by different indi-cate significant differences at the $p<0.05$ level according to the Least Significant Difference Test)

Jumlah akar dan panjang akar berpengaruh sangat nyata terhadap interaksi zat pengatur tumbuh dan jumlah ruas pada stek pucuk pada hari ke-130 hst (Gambar 3). Jumlah akar pada hari ke-130 hst, stek yang diberi perlakuan zat pengatur tumbuh atonik, stek tiga ruas $\left(\mathrm{A}_{1} \mathrm{~B}_{3}\right)$ menumbuhkan akar rata-rata 9,00 buah, sedangkan yang paling sedikit adalah $\mathrm{A}_{2} \mathrm{~B}_{1} \mathrm{~A}_{2} \mathrm{~B}_{2}$, $\mathrm{A}_{2} \mathrm{~B}_{3}$ dan $\mathrm{A}_{4} \mathrm{~B}_{1}$ yang belum menumbuhkan akar
(Tabel 4). Atonik merupakan zat pemacu pertumbuhan sintetik yang berfungsi merangsang pertumbuhan akar, mengaktifkan penyerapan unsur hara, meningkatkan keluarnya kuncup dan meningkatkan kualitas hasil tanaman (Surachmat, K. 1984). Menurut Ashari (1995) ; Heddy (1989), atonik termasuk dalam kelompok auksin yang mengandung bahan aktif natrium otrho-nitrofenol, natrium para-nitrofenol, 
natrium 2-4 dinitrofenol, dan natrium 5 nitroguaiakol. Senyawa tersebut sangat efektif dalam mengatur pertumbuhan akar, meningkatkan keberhasilan perakaran stek, mempercepat perakaran, dan meningkatkan kualitas akar adventif. Proses munculnya akar adventif terdiri dari tiga tahap yaitu 1. terjadi diferensiasi sel yang diikuti dengan terbentuknya sel-sel meristematis (inisiasi akar), 2. diferensiasi sel-sel meristematis hingga terbentuknya primordia akar, dan 3. mulai munculnya akarakar baru (Ashari,1995). Tetapi menurut Huik (2004) pemberian konsentrasi yang tinggi atau di atas normal, auksin dapat bersifat sebagai inhibitor karena enzim tidak bisa menangkap konsentrasi tersebut sehingga cenderung untuk menghambat pertumbuhan. Sehingga pemakaian suatu zat perangsang akar harus tepat konsentrasinya.

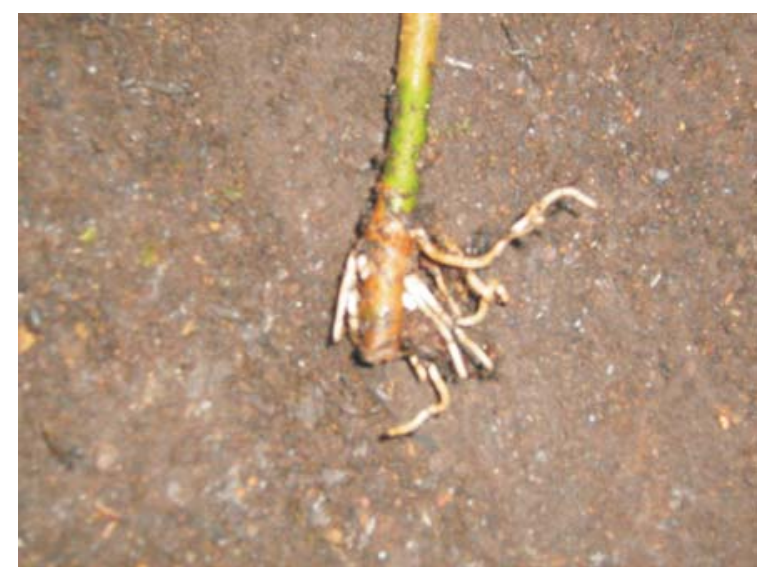

Gambar (figure) 3. Akar pada stek (roots in node)

Akar yang paling panjang tumbuh adalah pada stek yang diberi perlakuan zat pengatur tumbuh atonik, stek beruas tiga dengan rata-rata panjangnya $3,37 \mathrm{~cm}$ (Tabel 2). Hal tersebut disebabkan atonik merupakan kelompok auksin yang mempengaruhi aktivitas pemanjangan sel sehingga merangsang pertumbuhan panjang akar. Pemanjangan sel terjadi karena auksin mempengaruhi pengembangan dan pelenturan dinding sel. Auksin memacu protein tertentu yang ada di membran plasma sel tumbuhan untuk memompa ion $\mathrm{H}^{+}$ke dinding sel. Ion $\mathrm{H}^{+}$ini mengaktifkan enzim tertentu sehingga memutuskan beberapa ikatan silang hydrogen rantai molekul selulosa penyusun dinding sel. Sel tumbuhan kemudian memanjang akibat air yang masuk secara osmosis. Setelah pemanjangan ini, sel terus tumbuh dengan mensintesis kembali material dinding sel dan sitoplasma (Hidayanto, $d k k ., 2007)$.
Sedangkan yang paling pendek adalah $\mathrm{A}_{2} \mathrm{~B}_{1}, \mathrm{~A}_{2} \mathrm{~B}_{2}, \mathrm{~A}_{2} \mathrm{~B}_{3}$ dan $\mathrm{A}_{4} \mathrm{~B}_{1}$ yang akarnya belum tumbuh. Menurut Krishnamorthy dalam Sutatar T dan L. Sanjaya, (1996) tidak tumbuhnya akar disebabkan peningkatan kandungan auksin yang memungkinkan menurunnya ketidak aktifan auksin atau meningkatnya sintesis auksin. Di dalam sel tanaman IAA teroksidasi menjadi tidak aktif oleh peroksidase dan IAA oksidase. Auksin hanya dapat bereaksi pada batas konsentrasi tertentu, di atas konsentrasi tersebut auksin dapat bersifat toksik atau menghambat aktifitas pemanjangan sel (Priyono dan Mawardi,1993).

\section{KESIMPULAN}

Dari hasil penelitian dapat disimpulkan bahwa dalam memperbanyak pranajiwa dengan vegetatif (stek pucuk) yang paling baik digunakan adalah zat pengatur tumbuh atonik dengan stek pucuk yang beruas tiga $\mathrm{A}_{1} \mathrm{~B}_{3}$ dengan persentase hidup $90 \%$, pertumbuhan jumlah daun 2,90 helai, tinggi $0,77 \mathrm{~cm}$, panjang akar 3,37 $\mathrm{cm}$ dan jumlah akar $9,00 \mathrm{~cm}$.

\section{DAFTAR PUSTAKA}

Ardaka, IM., IN. Sudiatna, dan Hartutiningsih, M. Siregar. 2007. Pengaruh Berbagai Media terhadap Pertumbuhan Stek Purnajiwa (Euchresta horsfieldii (Lesch.) Benn). Prosiding Seminar Konservasi Tumbuhan Usada Bali dan Peranannya dalam Mendukung Ekowisata Bali. Kebun Raya Bali 6 September 2007. Hal. 309313.

Ashari, S. 1995. Hortikultura Aspek Budidaya. Universitas Indonesia. Jakarta.

Hartman, H.T. dan D.E.Kester, 1977. Plant Propagation Principles and Practise. Prentice Hall, Englewood Cliffs, New Jersery.

Hartutingsih M. Siregar dan I Nym. Peneng, 2003. Konservasi Pranajiwa (Euchresta horsfieldii (Lesch.) Benth) Fabaceae dan Upaya Perbanyakannya. UPT Balai Konservasi Tumbuhan Kebun Raya "Eka Karya" Bali-LIPI, Candikuning, Baturiti, Bali

Heddy, S. 1989. Hormon Tumbuhan. CV. Rajawali. Jakarta 
Heyne,K.1987. Tumbuhan Berguna Indonesia. Balitbang Kehutanan. Departemen Kehutanan Indonesia. Badan Penelitian dan Pengembangan Kehutanan Jakarta. Penerbit Yayasan Sarana Wana Jaya, Jakarta.

Hidayanto, M., S. Nurjanah dan Yossita. 2007. Pengaruh Panjang Stek Akar dan Konsentrasi Natrium Nitrofenol terhadap Pertumbuhan Akar Stek Sukun (Artocarpus communis F.). Available at: http://bbp2tp.litbang.deptan.go.id. Diakses tanggal 5Desember 2009.

Huik, E. M. 2004. Pengaruh Rooton F Dan Diameter Stek terhadap Pertumbuhan Batang dari Stek Jati (Tectona grandis L. F). Jurusan Kehutanan Fakultas Pertanian Universitas Pattimura. Ambon
Priyono dan S. Mawardi.1993. Kajian Penggunaan Pisang sebagai Penaung pada Kopi dan Kakao. Penyediaan Bibit secara in Vitro, Pembentukan dan Perakaran Bud Like Body pada Musa paradisiaca. Pelita Perkebunan 9.

Surachmat, K. 1984. Zat Pengatur Tumbuh Tanaman. CV. Yasagama.

Sutatar, T. dan L.Sanjaya,1996. Pengaruh Pemberian Zat Pengatur Tumbuh terhadap Pertumbuhan Vegetatif dan Generatif Anggrek Dendrobium hibrid. Prosiding Seminar Nasional Tanaman Hias: Balai Penelitian Tanaman Hias 